\title{
Recommendation of prior literature search
}

\author{
Yuji SUZUKI
}

Keywords: prior literature search; patent search; technology trend survey

\section{1.はじめに}

日本アルミニウム協会の特許委員会では，本誌の毎年第 4 号に, 知的財産に関する解説を掲載しており ${ }^{1)-5)}$, 本報で 6 回 目となります。

研究開発とは，今までになかった新しい知見を見出した り，特性の良いものを創造したりしようとする活動であり， 「新しい」ということを示すためには，「今」を正確に知って おくことが求められます。また, 研究開発の成果を特許とい うかたちで権利を取得し，事業の保護を求めるときも新規性 が必要となります。膨大な文献情報から欲しいものを短時間 で探し出すために, 調査用の検索ツールもいろいろと進化し ています。本解説では研究開発に携わる研究者・技術者に とって, 日ごろから久かせない先行技術調査の一端について 紹介します。

\section{2. 先行技術調査の目的}

研究者にとって, 自分の会社, 研究所や学校で行っている 研究や開発について, 他の誰かがすでに行っているにもかか わらず，それを知らずに同じことをやっているということは ないでしょうか？ 研究開発活動は一人だけで行っている ケースは少なく, 他の共同研究メンバーの経験・知見もある ため, なかなかそのようなことにはなることも少ないでしょ う。しかし，もしも他の誰かが自分の行っている分野と似た 技術についての研究開発を先に行っていて，その成果が公表 されていれば，その成果を基にしてさらなる高みを目指すこ とも可能になります。

先に研究あるいは開発を行っていた者が, それを秘密にし ていてどこにも発表や公開等をしていなければ，自分が独自 に見出した新しい知見ということができるでしょう。また，先 の発表がまだ仮説の段階であり，結果が同じように出たこと により仮説の検証となって，意義ある成果と言えなくもありま せん。しかし, 先に発表されていたことと同じことを後から発 表しても，創造，創作，発見，発明とは言いにくいものです。
また，新しい創造や発明を特許として出願することで，他 社の実施を阻止できるようになるのですが，特許として認め られるかどうかの判定基準のうちの1つは，他のどこにも発 表や公開されていたものではないものということです。した がって，すでに知られているような発明は特許にはできず， 出願や審査請求の費用が無駄になってしまいます。

さらに，自社でこれから製品を製造しようとする計画が あったり，実際に製造していたりするものやその製造方法が 他社の特許請求の範囲に含まれているようであれば, 特許権 侵害として訴えられる危険も生じてきます。また, 自社の事 業に支障がある他社特許に対して，それを無効化したい場 合，その特許発明が出願時に知られていた技術であったり， 知られていた技術から容易に思いつく技術であったことを異 議申立や無効審判等を請求することができます。この場合, 無効であることが認められれば自社の事業展開が大きく変 わってくることもあります。

\section{3. 先行文献とは何か?}

先行文献とはどんなものをいうのでしょうか。一般的には 図書, 雑誌等の学術文献であったり, 論文発表や学会発表で あったりします。また，特許公報やインターネットで公開さ れている情報も含まれます。日本で発表されているものだけ でなく，外国で公開されている情報も含まれます。このなか で，図書や杂隹誌は，図書館等でも検索ツールが提供されてい ますし，インターネットでも学術論文はdialog, J-dream III, J-STAGE等さまざまなデータベースが作成されて検索できる ようになっています。収録されている技術分野，情報の範囲 や収録期間，検索方法についてはそれぞれのデータベースの ホームページ等を参照していただきたいと思います。

\section{4. 特許情報とは}

\section{1 日本の特許文献}

特許文献も重要な先行技術の1つです。特許出願に係る書 類は, 願書, 特許請求の範囲, 明細書, 要約, 図面から構成

株式会社UACJ 技術部知的財産グループ（†455-8670 愛知県名古屋市港区千年3-1-12） Intellectual property section, UACJ Cooporation（3-112 Chitose, Minato-ku, Nagoya-shi, Aichi 455-8670)

責任著者E-mail：suzuki-yuji@uacj.co.jp

受付日：2019年12月10日＼cjkstart受理日：2020年2月18日 
されています。願書には, 出願人, 発明者等が記載されてい ます。明細書には，発明の名称，技術分野，発明の概要とし て発明が解決しようとする課題, 課題を解決するための手 段，発明の効果，発明を実施するための形態，実施例などが 記載されています。特許庁に特許出願されると, 出願番号, 出願日が付与されます。また，優先権主張を伴う出願の場合 は優先権主張番号, 優先日, 優先権主張国が付与され, 分割 出願の場合は原出願番号および原出願日が付与され，国際出 願から移行した出願の場合，国際出願番号および国際出願日 が付与されます。出願日または最先の優先日から18か月経過 すると, 公開番号, 公開日, 分類が付与されて公開されます。 このうち, 特許請求の範囲と明細書および図面以外の項目は 書誌的事項と呼ばれます。あまり気が付かないですが，書誌 的事項には発行特許庁や公報種別も含まれます。これらの書 誌的事項は INID (Internationally agreed Numbers for the Identification of Data）コードと呼ばれる書誌的事項の識別番 号が付与されており，異なる出願国で発行された特許公報で も同じ項目には同じINIDコードが付与されていますので，見 ただけではよくわからない言語の公報でもどの項目であるか はある程度わかるようになっています。よく用いられるINID コードとその内容を表 1 に示します。

\section{2 外国の特許文献}

日本以外の国や地域に出願された特許も，それぞれの国ま たは地域の法制度に従い, 所定の条件により基本的には公報 が発行されています。多くの場合，その国の母国語または公 用語となっています。特異なところとしては, 夕イでは出願 書類が所定の要件を満たしているかについての方式審査があ り，方式審査を経て出願人が公開料を納付しないと公開公報 が発行されませんので, 出願から18か月以上経ってから公開 公報が発行されます。また，早期の公開を希望すれば18か月 を経過する前に公開公報が発行されるところもあります。特 に中国では公開されないと審査が開始されない制度になって いるため，早期の権利化を希望する出願については早期公開 請求され，出願後まもなく公開公報が発行されています。

\section{5. 先行技術調査用特許検索サイト}

\section{1 特許情報プラットフォーム（J-PlatPat）}

日本の特許情報は，特許庁が発行したものを独立行政法人

表 1 よく用いられるINIDコードとその内容

\begin{tabular}{c|l}
\hline \hline $\begin{array}{c}\text { INID } \\
\text { コード }\end{array}$ & \multicolumn{1}{|c}{ 内容 } \\
\hline$(11)$ & 特許文献の番号（公報番号） \\
$(21 ）$ & 出願番号 \\
$(22)$ & 出願日 \\
$(31)$ & 優先権のもととなった出願の番号（優先権主張番号 $)$ \\
$(32)$ & 優先権のもととなった出願の日（優先日） \\
$(43)$ & 公開日 \\
$(51)$ & 国際特許分類 \\
$(54)$ & 発明の名称 \\
$(57)$ & 要約または特許請求の範囲 \\
$(71)$ & 出願人名 \\
$(72)$ & 発明者名 \\
\hline
\end{tabular}

工業所有権・研修館（以下，INPIT）をはじめとして，いろ いろな特許情報提供事業者が提供しています。INPITでは, 特許庁の 2 階に公報閲覧室を開設し，特許公報等を検索・閲 覧できる設備を一般にも開放しており，誰でも自由に無料で 閲覧用機器を使用して特許情報を閲覧することができます。 また，インターネット上でも，特許情報プラットフォーム （以下，J-PlatPat）で，特許情報を閲覧できます。以下に， J-PlatPatで検索する手順を紹介します。

まず, J-PlatPatのホームページ (https://www.j-platpat.inpit. go.jp/) ヘアクセスします。特許庁やINPITのホームページに リンクがありますので，そこからアクセスすることもできま す。

J-PlatPatで調査できるものは，国内外 1 億件以上の特許・実 用新案・意匠・商標の公報や審査経過記録等の情報です。日 本特許庁から発行されたデータと, 一部の外国（米国, 欧州, WO, 中国, 韓国, ドイツ, フランスほか）のデータが収録 されています。中国，韓国は機械翻訳された和文のデータも あります。機械翻訳については，以前はなかなか理解しにく い和訳でしたが、コンピュータの進歩により，だんだんとわ かるようになってきました。これからは $\mathrm{AI}$ 等の導入により， より忠実な翻訳が提供されることが期待されます。

(1) 番号で検索する

調べたい特許文献の番号がわかっている場合の検索方法で す。番号を入力する形式があっていれば, 必要な文献が確実 にヒットします。画面の上部のバーにカーソルを当てると詳 細メニューが開き，その中の番号照会ボタンをクリックし， 発行国，番号種類を選択し，番号欄に文献番号を入力して照 会ボタンをクリックします。複数の文献をスペースで区切っ て入力することで， 1 度に 20 件まで検索できます。発行国や 公報種別が異なる場合は，行を変えて番号を入力できます。 照会ボタンをクリックすると，該当する文献があれば番号が 表示され，番号をクリックすると公報の内容が表示されま す。内容の表示はテキストとPDF形式を選択でき, 文献単位 PDF 表示ボタンをクリックして認証コードを入力すること で, 1つの文献全体を1つのPDFファイルで表示することがで きます。

拒絶理由通知書や補正書, 意見書等の審査情報は, 経過情 報ボタンをクリックすると書類の一覧が表示され，リンクの ある書類はその書面が表示されます。OPDボタンをクリック すると, 外国のパテントファミリーの審査状況が閲覧できま す。OPDとはワン・ポータル・ドシエ (One Portal Dossier)の 略で, 各国の審査書類（ドシエとはフランス語で, 関連書類, 事件記録の意）をまとめて閲覧できる場所となっています。 パテントファミリーとは, 複数の国の同じ特許を共通する優 先権でつなげているものです。

(2) キーワードで検索する

ホームの画面の上部のバーにカーソルを当てると詳細メ ニューが表示され，その中の「特許・実用新案検索」をクリッ クします。選択入力では, テキスト検索対象を選択し, 検索 キーワード欄の検索項目を選んで，キーワード闌に検索した いキーワードを入力し, 必要に応じて除外キーワードや, 検 索オプションの主テーマ, 副テーマ（Fタームの技術分野を 示すコード番号：詳細は後述します）で絞込み，検索ボタン をクリックします。複数のキーワードをスペースで区切って 
入力すると OR 検索で和集合となります。各項目はAND検索 で積集合となります。J-PlatPatでのキーワード検索は類義語 や同義語，表記叻机（全角/半角，大文字/小文字，抑音/拗 音）には対応していないため, 検索もれを少なくするために は，類義語や同義語を適切に選定し，表記ゆれも網羅しない と欲しい文献を抽出できないということになりやすいので注 意が必要です。任意の1文字に代用できる文字として「?」が 使用できます。その場合，キーワードを「’」で囲む必要があ ります。また, 出願が電子化される以前の公報のデー夕は, 紙に印刷された文字をOCRで読及取って変換された文字 データですので，誤変換も含まれる可能性があることに注意 してください。

(3) 特許分類で検索する

J-PlatPatでキーワード検索する場合，類義語や同義語，表 記ゆれに気を付けないと検索もれ（必要な文献が抽出されな いこと）やノイズ（関係ない文献が抽出されること）が多く なります。それを回避するために, 特許分類を用いた検索が 有効です。特許分類は数字と記号の組み合わせなので, 直感 的にわかりにくいですが，キーワードで検索する場合に比べ て必要な文献だけを収集でき，ノイズの混入も抑えられるの で，ぜひ利用してほしい検索方法です。

特許分類とは特許庁に打いて発明の内容を技術の専門家が 判断して付与しているもので, 国際特許分類, FI, F夕ーム, 共通特許分類等があります。

(1) 国際特許分類（IPC：International Patent Classification) ほぼすべての国で採用されている特許分類です。

特許出願されたすべての発明の技術分野を，最初は大きく 仕分け（セクション），それを少し細かく仕分け（クラス）, そこからさらに細かく仕分け（サブクラス）ていくことを繰 り返した（メイングループ，サブグループ）ものです。ヒト に例えれば, 生物一動物 - 脊椎動物 一 ほ乳類 - 霊長類 - ヒ卜 というように順々に細かく仕分けていくように，すべての特 許出願について，国際的に統一された技術分野に，統一され た分類が付与されています。まず，大きな技術分野（セク ション： $\mathrm{A} \sim \mathrm{H}$ ) を先頭とし, 数字 2 けた (クラス), 英字 1 文 字 (サブクラス)，スペース，数字1〜2文字（メイングルー プ)，区切り文字「/」を挟んで数字 $1 \sim 4$ けた（サブグループ） で記述されます。図1㧍よび図2にIPCの基本的な構造を示し ます。

(2) FI (File Index)

FIは，国際特許分類をさらに細分化したもので，日本特許 独自のものです。FIはIPCの後に付加するように記述されま す。

(3) F夕ーム

Fタームは，全技術分野（約 2,600）のうち7割程度の技術 分野（約 1,800）に打いて，一定の技術範囲ごとに区分された テーマを作成し，技術的観点で細分化したものです ${ }^{6)}$ 。これ も日本特許独自の分類です。

（4）共通特許分類（CPC：Cooperative Patent Classification）

2013 年に旧 · 欧州特許分類（ECLA）に旧・米国特許分類 （USPC）が統合された特許分類で，旧・欧州特許分類を引き 継いだものです。CPCもIPCを細分化したものでありますが， FI とは異なった分類体系となっています。中国特許庁と韓国 特許庁などいくつかの外国特許庁が CPC プログラムに参加
を表明しており，IPCとともにCPCも付与されています。

(5) 特許分類の特徵

特許分類は，広い技術分野を段階的に細かく仕分けしてい るもので，技術分野が細かくなるにつれて分類記号の文字数 が増える構造になっています。そのため, 広い技術分野で検 索したい時にはサブクラスやメイングループまでにすればよ いですし，狭い技術分野で検索したい場合はサブグループま で入力して検索するようにするとよいでしょう。

\section{2 外国特許検索}

\section{2. 1 Espacenet}

Espacenet (https://worldwide.espacenet.com $/$ ? locale $=$ jp_EP $)$ は，欧州特許庁が作成したINPADOC というパテントファミ リーのデータベースを利用した特許検索のオンライン・サー ビスで，90以上の国の特許公報を収録しています。

前記URLで示した検索ページでは, 日本語表記となり, 検 索項目やヘルプの一部が日本語で表示されます。「高度の検 索」を選択すると, 番号検索, タイトルまたは要約, 出願人, 発明者でのキーワード検索, IPCまたはCPCでの分類検索が 可能です。

検索結果から Patent familyボタンにより, 当該出願のファ ミリーの一覧が表示されますので，その発明が出願されてい る国が簡単にわかるので便利です。欧州特許出願に関して は, Patent register との連携により, 欧州特許庁の審査経過情

\section{22 C $21 / 00$}

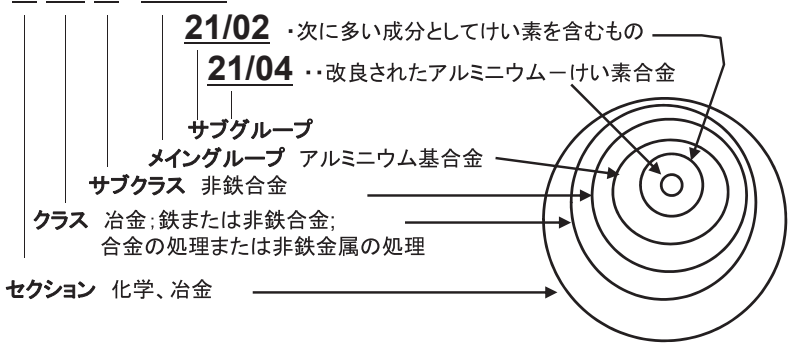

\begin{tabular}{|l|l|l|}
\hline IPC & ドット & 説明 \\
\hline C22C 21/00 & & アルミニウム基合金 \\
\hline C22C 21/02 & • & 次に多い成分としてけい素を含むもの \\
\hline C22C 21/04 & - & 改良されたアルミニウムけい素合金 \\
\hline C22C 21/06 & - & 次に多い成分としてマグネシウムを含むもの \\
\hline C22C 21/08 & - & 1い素を含むもの \\
\hline C22C 21/10 & - & 次に多い成分として亜鉛を含むもの \\
\hline C22C 21/12 & - & 次に多い成分として銅を含むもの \\
\hline C22C 21/14 & $\cdots$ & けい素を含むもの \\
\hline C22C 21/16 & $\cdots$ & マグネシウムを含むもの \\
\hline C22C 21/18 & $\cdots$ & 亜鉛を含むもの \\
\hline
\end{tabular}

図1 IPCの構造

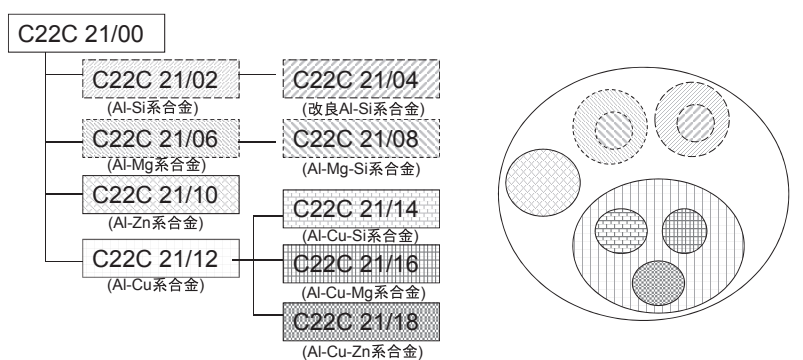

図2 アルミニウム基合金のIPC 
報がわかるようになっています。

\section{2. 2 PATENT SCOPE}

PATENT SCOPE（https://patentscope.wipo.int/search/ja/）は, 世界知的所有権機関 (World Intellectual Property Organization WIPO）が提供する特許データベース検索サービスであり，公 開済みの PCT 国際出願をはじめ, 国内特許文献の検索が可 能となっています。

検索のホームページは, 日本語表記も可能です。「構造化検 索」では，番号検索，全文，夕イトル，要約，出願人，発明 者でのキーワード検索が可能です。国際出願については，国 内段階に移行した国の出願番号と移行日がわかるようになっ ていますが，表示されていない国でも移行している場合があ りますので, 注意が必要です。

\section{3 合金成分による検索}

この「軽金属」の読者には, 合金の研究開発に携わってい る研究者も多いでしょう。合金の研究・開発としては, ベー ス金属に他の元素を添加して，その量を調整することによっ て新たな特性を得ることが多いと思われますが，合金中の他 の元素の含有量で検索できるツールはまだ多くありません。 その中で，日本特許について合金中の含有量で検索できる ツールがINPIT の公報閲覧室（特許庁本庁舎 2 階）と近畿統 括本部 (大阪市北区大深町 グランフロント大阪ナレッジキャ ピタルタワーC9階)において，日本特許庁の審査官が使う機 器と同等のサーチ・閲覧機能をもつ「高度検索閲覧用機器」 を用いたICIREPAT (合金) 検索として提供されています。こ の ICIREPAT 検索のデータベースには, ベース合金（A夕ー ム), 含有成分と含有量の上下限 (B夕ーム), 性質・用途 $(\mathrm{C}$ ターム)，プロセス（Dターム）が独自の検索キーとして収録 されています。例えばアルミニウム基合金中に銅が 0.5 〜 $1.0 \%$ 含有するという条件で検索すると，同じく $0.1 \sim 0.6 \%$ 含 有する特許 $\mathrm{A}$, 同じく $0.8 \sim 2.0 \%$ 含有する特許 $\mathrm{B}$, 同じく 0.7 $0.8 \%$ 含有する特許 Cを抽出し，同じく $0.10 \%$ 以下を含有する 特許 $\mathrm{D}$, 同じく $5 \sim 8 \%$ 含有する特許 $\mathrm{E}$ は抽出しない検索結果 が得られます（図3）。必須として含有する元素，選択含有元 素, 不純物元素の識別も可能となっています。1つの出願中 に含有成分範囲の異なる請求項がある場合, クラッド材など 心材と皮材といった複数の合金成分が記載されている場合 は，データが複数収録されています。なお，ベース合金は金 属だけでなく，金属間化合物，酸化物や有機化合物でも検索 が可能となっています。

合金検索と分類検索やキーワード検索は連携されています ので，合金成分で検索した結果を分類やキーワードで絞り込 むことも可能です。利用できる場所と時間が限定され，検索

\section{AL/AT Aターム(ベース金属) \\ $C U: 0.5 \mathrm{~V} 1.0 / \mathrm{BT} \quad \mathrm{B}$ ターム(合金成分と含有量)}

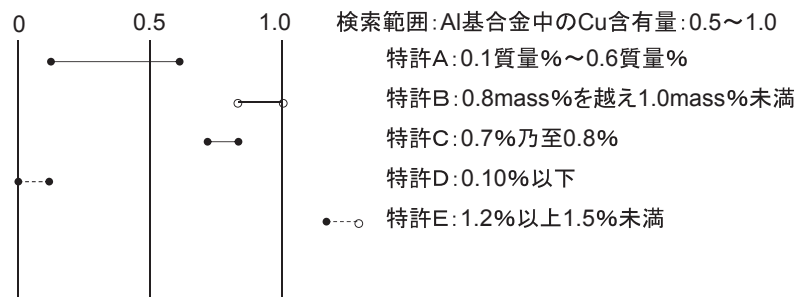

図3 ICIREPATによる合金成分の範囲検索（実線：抽 出, 破線：非抽出）
結果は紙に出力することしかできない等の利用制限はありま すが, 合金の研究開発者は, ぜひ利用してはいかがでしょう か。

\section{6. 先行文献調査のタイミング}

\section{1 技術動向調査}

特許の出願動向は，その分野における最先端（正確にいえ ば 1 年半前）の技術に関するものであるため，どんな企業や 研究機関がどのような技術分野の開発に注力していて，その 技術分野にはどのような課題があって，それらの課題をどの ようにして解決していこうとしているかが見えてきます。そ れらを適切に分析し，他社が権利を取得しようとしているも のをうまく避けながら，さらに改良技術の開発を進めるな ど, 自らの研究・開発の進め方に反映することができれば, 効率的な研究・開発が進められるようになります。これらの 技術情報は，日々新しい文献が発行されていくため，定期的 に行うことが望まれます。新しく発行された文献を見逃さな いようにするためには，文献の発行日ごとに検索することが 望まれますが，キーワードや技術分野といった検索式をあら かじめ検索ツールに設定しておき，データが更新されるごと に検索結果を配信するようにしておくと，見逃しが防止でき ます。

\section{2 開発開始段階}

自社が新規に開発を進めることになった場合, 前項で述べ た技術動向調査を十分に行ったとすれば，他社が特許権を確 保しているもの，他社が特許出願を行っていて権利を確保し ようとしているものを十分に把握しておくことが望まれま す。もしも，他社が権利を保有していたことを知らずに，多 くの費用をかけて開発を進めて良好な結果が得られたため量 産となることが決まった後に，または量産に移ってしまって から他社が確保している特許請求の範囲に該当するものであ ることが判明すると, 特許権者との間で問題になるおそれが あるからです。また，他社の特許権または出願中の他社特許 の特許請求の範囲に該当していた場合に，特許が無効となる ベきものであるとか, 審査の過程で範囲が減縮であることが 確実視される場合であっても, 無効の判断や範囲の減縮は予 想が極めて難しいので，知財の専門家を含めて十分に検討す る必要があります。

\section{3 新規特許出願段階}

研究・開発の成果を基に発明が完成し，新規に特許出願す る場合は, 出願しようとする特許請求の範囲に基づいて, 新 規性および進歩性について先行技術の調査が必要となりま す。さらに, 審査請求を公開後に行うときは, 出願時に未公 開であったために先行技術調査で見つからなかった他社出願 も公開されているため, 審査請求を行う時点でもう一度先行 技術調査を行って，新規性判断に影響があるようなものが見 つかったら，新規性があるように補正することを検討するこ とが望ましいと思われます。

\section{7. まとめ}

先行技術調査は, 企業や研究機関の研究・開発の方向付け の礎になるのみならず，特許査定を受けやすい出願にするこ とが可能となり，また他社との特許紛争の回避につながるも ので，企業活動における無用な費用を抑えることになりま 
す。データベースや検索ツールは今後も一層進化し続けると みられ，この解説で述べたことを特段に意識しなくても容易 に検索できる時代がやってくることも期待されますが，検索 の基本を理解していただけますと幸いです。

最後になりましたが，この原稿を作成するにあたり，監修 等いただきました日本アルミニウム協会特許委員会の委員各 位，取りまとめいただきました協会事務局の見原部長に感謝 の意を表します。なお, 記事の内容は, 2019年11月時点のも のです。

\section{参 考 文 献}

1）稲林芳人：特許出願と技術流出，軽金属， 65 (2015), 138-143,

2）青木一男：特許出願に扔ける拒絶理由通知対応，軽金属，66 (2016), 185-191.

3）小林智明：共同研究開発と特許出願, 軽金属, 67 (2017), 110117.

4）本川治己：引用の仕方，軽金属，68（2018），207-210

5）横井慶一：忘れていませんか！外国への特許出願, 軽金属, 69 (2019)，264-268

6）独立行政法人工業所有権情報 - 研修館 : 国際特許分類, FI, F タームとそれらを用いた先行技術調査，(2018），34-45. 